\title{
Macronutrient fertilizers on basil growth and yield
}

\author{
Janderson do Carmo Lima ${ }^{*}{ }^{\oplus}$, Marilza Neves do Nascimento ${ }^{(\oplus)}$,

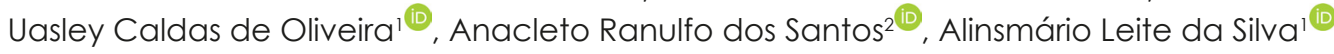

State University of Feira de Santana, Feira de Santana, Brazil

${ }^{2}$ Federal University of Recôncavo da Bahia, Cruz das Almas, Brazil

*Corresponding author, e-mail: janderson_ufrb@yahoo.com.br

\begin{abstract}
The objective of this work was to determine the macronutrient doses that allow the highest phytomass yield and growth of basil plants. The experiment was carried out in the experimental area of the Federal University of Recôncavo da Bahia, in Cruz das Almas, BA, in a greenhouse. The treatments were obtained according to the Baconian matrix statistical arrangement, in which one of the nutrients is supplied in variable amounts, while the others are kept at a referential level. Six nutrients (nitrogen (N), phosphorus (P), potassium (K), calcium (Ca), magnesium (Mg) and sulfur (S)) were evaluated in three different doses, and two additional treatments, one with reference doses and another without nutrient addition, totaling 20 treatments that were arranged in a completely randomized design with five replications, totaling 100 experimental units. At 50 days after treatment distribution, the growth parameters were evaluated: Plant height, number of leaves, leaf dry mass, stem, root and leaf area. It was observed that the highest leaf dry mass accumulation was estimated with the dose of 250 $\mathrm{mg} \mathrm{dm^{3 }}$ of $\mathrm{N}$ giving an average of $8.01 \mathrm{~g}$ per plant, being significantly higher when compared to all other tested elements, this parameter is extremely relevant because the leaves are characterized as the main product of this species. Phosphorus doses allowed significant results in height and leaf area, whereas $\mathrm{K}$ favored higher leaf emission. Positive responses were verified for nutrients $\mathrm{Ca}, \mathrm{Mg}$ and $\mathrm{S}$ in all parameters tested at levels above those tested as reference.
\end{abstract}

Keywords: Ocimum basilicum L., medicinal plants, soil fertility

\section{Introduction}

Basil (Ocimum basilicum L.), is a medicinal and aromatic plant, which has its origin in Southwest Asia, belonging to the Lamiaceae family, is commonly used in the food, pharmaceutical and cosmetic industries (Hanif et al., 2011; Oliveira et al., 2013).

In Brazil, the use of medicinal plants is quite prominent, where the procurement is done mainly by extractivism (Blanketal., 2004). Asaresult, themanagement of these plants is conducted in a non-standard way, which may affect the production of phytomass and essential oils (Furlan, 2000; Blank et al., 2012). The country also has significant market projections, as it has a large territorial extension and varied edaphoclimatic conditions, thus allowing a great diversity of plant species that can be incorporated into food, making of cosmetics and herbal medicines (Brasil, 2012; Pereira \& Cardoso, 2012; Bione et al., 2014). Considering this great edaphoclimatic diversity, it is essential to know the chemical attributes of soils, as these are characterized as the main nutrient reserves for plants. According to Souza et al. (2006), the fertility of Brazilian soils presents itself as a limiting factor in the growth and production of medicinal plants in many commercial cultivation conditions. Thus, it is essential to investigate the nutritional requirements that each species presents.

The essential nutrients in plants are classified into two groups, macro (nitrogen $(N)$, phosphorus $(P)$, potassium (K), calcium (Ca), magnesium $(\mathrm{Mg})$ and sulfur (S)) and micronutrients, this distinction was based on studies, which proved the distinct need of these elements. Since these nutrients are needed to meet the essentiality criteria, where, in the absence of one or more, the plant cannot complete its life cycle, they cannot be replaced by other elements and these nutrients must directly participate in plant metabolism. Where they play 
important roles in the formation of various compounds and cellular structures (chlorophylls, enzymes, cell wall, DNA, plasma membrane, etc.) and also in several metabolic pathways, and can act as a signaling molecule or energy source (ATP, NADPH, FADH) (Malavolta, 1980). Knowing the importance of these nutrients, it is extremely relevant to know the edaphoclimatic conditions of the cultivation environment, because the nutritional demand can vary significantly. The need for fertilization in tropical soils is of great importance, because, in general, these soils are not able to naturally supply all the nutrients that plants need without compromising plant performance. According to Gonçalves et al. (2000), it is essential to understand the quantities and origin of fertilizers, taking into account the reactions that occur in the soil, the efficiency and the economic factors. Therefore, it is necessary to promote favorable conditions for plant growth and development, whether these are: humidity, relief, light, irrigation, climatic factors, soil fertility, among others; so that it is possible to provide plants with ideal conditions to express their maximum genetic potential (Calixto, 2000; Meira et al., 2012; Silva et al., 2015).

In view of the above, the objective of this work was to determine the doses of macronutrients that allow the highest phytomass yield and growth of basil plants.

\section{Material and Methods}

The experiment was carried out in the experimental area of the Federal University of Recôncavo da Bahia (UFRB), in the municipality of Cruz das Almas, BA, in a greenhouse, located at geographical coordinates $09^{\circ} 04^{\prime} 28^{\prime \prime}$ south latitude, $44^{\circ} 21^{\prime} 31^{\prime \prime}$ West longitude with an average altitude of $277 \mathrm{~m}$.

Samples of a dystrophic Argisol were collected in the $0-20 \mathrm{~cm}$ deep layer, from the municipality of Cruz das almas-Ba, on the UFRB campus. Then they were sent to the specialized laboratory for chemical characterization (Table 1), according to (EMBRAPA, 2011).

Table 1. Chemical characterization in the $0-20 \mathrm{~cm}$ deep layer in Argisol used in seedling production.

\begin{tabular}{|c|c|c|c|c|c|c|c|c|c|c|c|}
\hline $\mathrm{pH}$ & $P$ & K & $\mathrm{Ca}^{2+}$ & $\mathrm{Mg}^{2+}$ & $\mathrm{Al}^{3+}$ & $\mathrm{H}+\mathrm{Al}$ & SB & $\mathrm{CTC}(\mathrm{t})$ & $\mathrm{CTC}(\mathrm{T})$ & $\mathrm{MO}$ & $\mathrm{V}$ \\
\hline $\mathrm{H}_{2} \mathrm{O}$ & \multicolumn{2}{|c|}{$\mathrm{mg} / \mathrm{dm}^{3}$} & \multicolumn{7}{|c|}{$\mathrm{cmol}_{\mathrm{c}} / \mathrm{dm}^{3}$} & \multicolumn{2}{|c|}{$\%$} \\
\hline 5.6 & 0 & 0 & 0.8 & 0.5 & 0 & 1.5 & 1.32 & 1.32 & 2.82 & 0.96 & 46.81 \\
\hline
\end{tabular}

The treatments were obtained according to the statistical arrangement of the Baconian matrix (Turrent, 1979), in which one of the nutrients is supplied in variable amounts, while the others are maintained at a reference level. Six nutrients (nitrogen, phosphorus, potassium, calcium, magnesium and sulfur) were evaluated, in three doses, and two additional treatments, one with reference doses (Abreu et al., 2013; Lima et al., 2013; Ferreira et al.,
2016; Matos et al., 2016) and the other without added nutrients, totaling 20 treatments that were arranged in a completely randomized design, with five replications, totaling 100 experimental units. In order to configure the treatments, it was established that as the doses of one nutrient varied, the others established remained fixed (Table 2).

Table 2. Treatments used, obtained by the Baconian matrix with the respective doses of nutrients applied to the substrate.

\begin{tabular}{|c|c|c|c|}
\hline Treatments & Units & Treatments & Units \\
\hline Reference dose ${ }^{*}$ & $\mathrm{mg} / \mathrm{dm}^{3}$ e $\mathrm{cmol}_{\mathrm{c}} / \mathrm{dm}^{3}$ & $\mathrm{~K}=300^{* *}$ & $\mathrm{mg} / \mathrm{dm}^{3}$ \\
\hline Soil without fertilization & - & $\mathrm{Ca}=0.5^{* *}$ & \\
\hline$N=75^{* *}$ & & $\mathrm{Ca}=1.5^{* *}$ & \\
\hline $\mathrm{N}=225^{* *}$ & & $\mathrm{Ca}=2.0^{* *}$ & \\
\hline $\mathrm{N}=300^{* *}$ & & $M g=0.2^{* *}$ & $\mathrm{cmol}_{\mathrm{c}} / \mathrm{dm}^{\circ}$ \\
\hline$P=30 * *$ & $\mathrm{mg} / \mathrm{dm}^{3}$ & $M g=0.6^{* *}$ & \\
\hline $\mathrm{P}=90^{* *}$ & $\mathrm{mg} / \mathrm{am}$ & $M g=0.8^{* *}$ & \\
\hline$P=120^{* *}$ & & $S=20^{* *}$ & \\
\hline$K=75^{* *}$ & & $S=60^{* *}$ & $\mathrm{mg} / \mathrm{dm}^{3}$ \\
\hline$K=225^{* *}$ & & $S=80^{* *}$ & \\
\hline
\end{tabular}

Six (6) $\mathrm{kg}$ of soil was used as substrate in each plastic pot, which had a capacity of $6 \mathrm{dm}^{3}$, later the doses of calcium and magnesium were added to the soil, using a mixture of $\mathrm{CaCO}_{3}$ and $\mathrm{MgCO}_{3}$, in the quantities defined by the treatments and homogenized. After this application, the soils underwent an incubation period of 
45 days, in order to guarantee the effectiveness of the solubilization of the fertilizers used and the water content was kept close to $60 \%$ of the field capacity, according to Marques et al. (2015).

Subsequently, the other nutrients were added according to the amounts defined in Table 2. All fertilizers were applied at the time of planting, with the exception of nitrogen, which had its dose split, half carried out during planting and the other half applied 30 days after the first application. The salts used were: $\left(\mathrm{NH}_{4}\right)_{2} \mathrm{SO}_{4}$ for $\mathrm{N}$ and $\mathrm{S}$; $\mathrm{KH}_{2} \mathrm{PO}_{4}$ for $\mathrm{K}$ and $\mathrm{P} ; \mathrm{KCl}$ for $\mathrm{K}$ and $\mathrm{CH}_{4} \mathrm{~N}_{2} \mathrm{O}$ for $\mathrm{N}$.

Sowing was carried out in plastic polyethylene containers with a capacity of $0.3 \mathrm{dm}^{3}$, using three basil seeds per pot, which were obtained commercially (Feltrin $\AA$ brand). After 21 days, the most uniform seedlings were carefully selected, and later transplanted to the final pots/vessels.

At 50 days after the application of the treatments, the growth parameters, plant height (ALT) were evaluated, using a tape measure, measuring from the base of the plant until the insertion of the last pair of leaves, the number of leaves (NF) obtained through direct counting and the leaf area (AF) determined with the use of a perforator of known area (of metal), through punches, obtaining samples of leaf discs, relating the dry mass of the known area of the disc with the dry mass of the leaf, expressed in $\mathrm{cm}^{2}$ (Peixoto et al., 2011).

The leaves, stems and roots of $O$. basilicum plants were collected and packed individually in paper bags, placed in an oven, with forced air circulation, $45^{\circ} \mathrm{C} \pm 2{ }^{\circ} \mathrm{C}$, until reaching constant weight. Subsequently, after $72 \mathrm{~h}$, the variables dry mass of the leaf (MSF), stem (MSC), and root (MSR) were analyzed, using an analytical balance, with precision of three places. Subsequently, the values of shoot dry mass (MSPA) and plant (MSP) were determined. All these variables were expressed in $g$ of phytomass.

The data were interpreted statistically through the analysis of variance and regression, using the statistical program SISVAR. The response curves to the addition of the doses of each nutrient resulted in regression models in which the coefficients were tested based on the values of the mean square of the ANOVA residue, being analyzed at 1 and $5 \%$ probability (Ferreira, 2011).

\section{Results and Discussion}

It was verified, by the averages obtained for each parameter evaluated as a function of the treatments, that there was a significant response regarding the application of increasing doses of macronutrients in relation to the treatment without fertilization, thus characterizing that the fertilizers content $\mathrm{N}, \mathrm{P}, \mathrm{K}, \mathrm{Ca}, \mathrm{Mg}$ and $\mathrm{S}$ promoted significant growth in basil plants.

The lowest averages were observed in treatments without adding salts for the variables: ALT, NF, MSF, MSC, MSR, MSPA, MSP and AF. Highlighting this significant effect on the MSF parameter, an average increase of $82 \%$ was observed, in relation to the values found for plants grown without the addition of fertilizers (Table 3). It is also notable that there was a quadratic behavior depending on the doses studied for the six nutrients tested.

Through the responses obtained by the analysis of variance, it was observed that the application of fertilizers containing macronutrients promoted significant increases in the growth of $O$. basilicum plants in relation to the treatment without fertilization.

There was a significant effect at the level of $1 \%$ probability in the variables ALT, NF, MSF and MSC, in response to the six macronutrients tested. For the height of the basil plants, it was observed that $\mathrm{N}$ and $\mathrm{P}$ were the elements that provided the highest estimated values (70.3 and $72.2 \mathrm{~cm}$, respectively), being requested in quantities above those tested as a reference (Table 4). Considering the regression analysis, it was possible to estimate the best dose for each nutrient, while the others remained fixed at the reference level. Thus, the estimated doses (DE) for ALT were: N: 170; P: 91.25; K: 187.5 (values expressed in $\mathrm{mg} / \mathrm{dm}^{3}$ ); Ca: 1.14; Mg: 0.46 (both in $\mathrm{cmol}_{\mathrm{c}} / \mathrm{dm}^{3}$ ) and $\mathrm{S}$ : $51.66\left(\mathrm{mg} / \mathrm{dm}^{3}\right)$. Possibly the higher requirement of these elements, must be linked to the high degree of weathering of the studied soil, characterized by presenting low saturation by bases and CTC.

Ferreira et al. (2016) studying the effect of nitrogen fertilization and seasonality on basil plants, found ALT values lower than those found in this work, thus highlighting the ability of this species to maintain itself in adverse conditions, such as light, temperature and soil fertility.

Similarly, it was observed that $\mathrm{K}$ was the nutrient that presented the highest estimated mean value for the number of leaves, being 317 (unit value) using the dose of $260 \mathrm{mg} / \mathrm{dm}^{3}$ of $\mathrm{K}$. Thus, the DE for each element tested was: N: 178.57; P: 108.75; K: 260 (values expressed in mg/ $\mathrm{dm}^{3}$ ); Ca: 1.22; Mg: 0.5 (both in $\mathrm{cmol}_{\mathrm{c}} / \mathrm{dm}^{3}$ ) and S: 57.28 $\left(\mathrm{mg} / \mathrm{dm}^{3}\right)$.

Matos et al. (2016) studying the effect of luminosity and $\mathrm{K}$ concentrations in basil plants $\mathrm{CV}$. Maria bonita, found that at 30 days of cultivation the estimated dose for the highest NF was $99.5 \mathrm{~kg} \mathrm{ha}^{-1}$ of $\mathrm{K}$, with an average value of 177 leaves. Thus, comparing with this work it is possible to highlight that in the 20 days of difference in cultivation there was an estimated average increase of 
$78 \%$ in the number of leaves and also an increase in the requisition for this nutrient.

Potassium plays an important role in plant metabolism, despite not being a constituent of any structure or organic molecule, it is responsible for the activation of more than 60 enzymatic systems, has a direct role in photosynthesis, regulates the translocation of nutrients in the plant, increases absorption of $\mathrm{N}$ in addition to participating in the synthesis of starch in the leaves (Taiz et al., 2017).

Table 3. Averages for basil, depending on the application of increasing doses of Nitrogen (N), Phosphorus (P), Potassium (K) and Sulfur (S) in $\mathrm{mg} / \mathrm{dm}^{3}$ and Calcium (Ca) and Magnesium (Mg) in $\mathrm{cmol}_{\mathrm{c}} / \mathrm{dm}^{3}$, of the following characteristics: Height (ALT), Number of leaves (NF), dry leaf phytomass (MSF), stem (MSC), root (MSR), aerial part (MSPA), plant (MSP) and leaf area (AF), 50 days after the application of treatments.

\begin{tabular}{|c|c|c|c|c|c|c|c|c|c|}
\hline \multirow{2}{*}{ Nutrient } & \multirow{2}{*}{ Dose } & \multirow{2}{*}{$\mathrm{ALT}(\mathrm{cm})$} & \multirow{2}{*}{$N^{\circ}$ of leaves } & MSF & MSC & MSR & MSPA & MSP & \multirow{2}{*}{$\mathrm{AF}\left(\mathrm{cm}^{2}\right)$} \\
\hline & & & & \multicolumn{5}{|c|}{ - } & \\
\hline $\mathrm{N}$ & 0 & 35.9 & 32.4 & 0.96 & 0.54 & 1.2 & 1.49 & 2.7 & 71.39 \\
\hline$N$ & 75 & 73.5 & 262.6 & 6.7 & 5.0 & 7.2 & 11.7 & 18.93 & 404.06 \\
\hline $\mathrm{N}$ & 150 & 65.0 & 254.4 & 5.04 & 4.46 & 4.61 & 9.5 & 14.11 & 334.1 \\
\hline $\mathrm{N}$ & 225 & 58.2 & 244.2 & 4.84 & 3.71 & 3.89 & 8.55 & 12.44 & 287.05 \\
\hline $\mathrm{N}$ & 300 & 53.2 & 202.8 & 3.87 & 2.57 & 2.89 & 6.44 & 9.33 & 250.72 \\
\hline$P$ & 0 & 35.9 & 32.4 & 0.96 & 0.54 & 1.2 & 1.49 & 2.7 & 71.39 \\
\hline$P$ & 30 & 63.0 & 213.4 & 4.93 & 3.22 & 6.22 & 8.15 & 14.37 & 285.09 \\
\hline$P$ & 60 & 65,0 & 254.4 & 5.04 & 4.46 & 4.61 & 9.5 & 14.11 & 334.1 \\
\hline$P$ & 90 & 60.6 & 210.6 & 5.32 & 3.92 & 3.33 & 9.24 & 12.57 & 366.57 \\
\hline$P$ & 120 & 60.5 & 297.6 & 5.33 & 3.98 & 4.79 & 9.31 & 14.1 & 343.12 \\
\hline K & 0 & 35.9 & 32.4 & 0.96 & 0.54 & 1.2 & 1.49 & 2.7 & 71.39 \\
\hline K & 75 & 59.3 & 200.4 & 4.6 & 3.12 & 2.84 & 7.72 & 10.56 & 270.98 \\
\hline K & 150 & 65.0 & 254.4 & 5.04 & 4.46 & 4.61 & 9.5 & 14.11 & 334.1 \\
\hline K & 225 & 58.2 & 228.2 & 3.97 & 2.72 & 4.39 & 6.69 & 11.08 & 263.51 \\
\hline$K$ & 300 & 536 & 240.0 & 3.75 & 2.96 & 2.88 & 6.72 & 9.6 & 247.80 \\
\hline $\mathrm{Ca}$ & 0 & 35.9 & 32.4 & 0.96 & 0.54 & 1.2 & 1.49 & 2.7 & 71.39 \\
\hline $\mathrm{Ca}$ & 0.5 & 55.1 & 249.4 & 4.5 & 3.28 & 4.4 & 7.78 & 12.18 & 290.99 \\
\hline $\mathrm{Ca}$ & 1.0 & 65.0 & 254.4 & 5.04 & 4.46 & 4.61 & 9.5 & 14.11 & 334.1 \\
\hline $\mathrm{Ca}$ & 1.5 & 56.6 & 204.2 & 4.48 & 2.69 & 3.81 & 7.17 & 10.98 & 248.46 \\
\hline $\mathrm{Ca}$ & 2.0 & 49.2 & 207.2 & 3.38 & 2.35 & 4.43 & 5.74 & 10.17 & 222.62 \\
\hline $\mathrm{Mg}$ & 0 & 35.9 & 32.4 & 0.96 & 0.54 & 1.2 & 1.49 & 2.7 & 71.39 \\
\hline $\mathrm{Mg}$ & 0.2 & 55.0 & 231.8 & 4.39 & 2.78 & 3.93 & 7.18 & 11.11 & 307.53 \\
\hline $\mathrm{Mg}$ & 0.4 & 65.0 & 254.4 & 5.04 & 4.46 & 4.61 & 9.5 & 14.11 & 334.1 \\
\hline $\mathrm{Mg}$ & 0.6 & 55.0 & 243.2 & 4.31 & 2.84 & 3.44 & 7.15 & 10.59 & 284.89 \\
\hline $\mathrm{Mg}$ & 0.8 & 51.2 & 210.0 & 4.03 & 2.92 & 4.31 & 6.95 & 11.26 & 253.85 \\
\hline$S$ & 0 & 35.9 & 32.4 & 0.96 & 0.54 & 1.2 & 1.49 & 2.7 & 71.39 \\
\hline$S$ & 20 & 55.5 & 208.4 & 4.27 & 2.67 & 3.65 & 6.94 & 10.59 & 279.98 \\
\hline$S$ & 40 & 65.0 & 254.4 & 5.04 & 4.46 & 4.61 & 9.5 & 14.11 & 334.1 \\
\hline$S$ & 60 & 49.0 & 201.6 & 4.04 & 2.56 & 2.32 & 6.6 & 8.92 & 248.25 \\
\hline$S$ & 80 & 53.6 & 205.4 & 3.99 & 2.5 & 3.14 & 6.48 & 9.62 & 263.54 \\
\hline
\end{tabular}

For the variables MSF and MSC it was found that $\mathrm{N}$ was the nutrient responsible for the largest increments, being $8.01 \mathrm{~g}$ and $5.08 \mathrm{~g}$, respectively (Table 4). Thus highlighting the importance of this element in the growth and accumulation of phytomass, as it is a constituent of macromolecules and a direct participant in plant metabolism. The results of MSF are of great relevance, since it is characterized as the main commercialization factor in most medicinal plants, either for fresh use or for the extraction of essential oils. The estimated dose for each element considering the regression analyses for MSF are: $\mathrm{N}$ : 250; P: 86.66; $\mathrm{K}: 20$ (values expressed in $\mathrm{mg} / \mathrm{dm}^{3}$ ); Ca: 1.16; Mg: 0.5 (both in $\mathrm{cmol}_{\mathrm{c}} / \mathrm{dm}^{3}$ ) and S: 75 (mg/dm³). It is important to highlight that for $\mathrm{K}$ the best estimated dose was much lower than the concentration tested as a reference, probably through the mineralization of organic matter present in the soil (Table 1) this element was made available in quantities higher than estimated, yet it shows the low influence of this mineral for the dry mass of basil leaves. For MSC it was observed that the DE were: N: 200; $\mathrm{P}: 90 ; \mathrm{K}: 166.67$ (values expressed in $\mathrm{mg} / \mathrm{dm}^{3}$ ); Ca: 1.12; Mg: 0.49 (both in $\mathrm{cmol}_{\mathrm{c}} / \mathrm{dm}^{3}$ ) and S: $65\left(\mathrm{mg} / \mathrm{dm}^{3}\right)$. Using the estimated dose of $\mathrm{N}$ for MSF and considering a basil plantation with 60,000 plants per hectare, the production of $480.6 \mathrm{Kg} \mathrm{ha}^{-1}$ is estimated, being $14.3 \%$ (60 $\mathrm{Kg} \mathrm{ha}^{-1}$ ) higher than the estimated production in relation to the reference dose.

A significant effect was also observed at 5 and $1 \%$ probability for all macronutrients in the variables MSR, MSPA, MSP and AF (Table 5) with the exception of MSR 
Table 4. Estimates generated due to the application of increasing doses of $\mathrm{N}, \mathrm{P}, \mathrm{K}$ and $\mathrm{S}$ in $\mathrm{mg} / \mathrm{dm}^{3}$ and $\mathrm{Ca}$ and $\mathrm{Mg}$ in $\mathrm{cmol}_{\mathrm{c}} / \mathrm{dm}^{3}$, on the following variables: height (ALT), number of leaves (NF), dry leaf mass (MSF) and dry stem mass (MSC), in O. basilicum plants, Cruz das Almas-Ba, 2018.

\begin{tabular}{|c|c|c|c|c|}
\hline Variables & Nutrients & Equation & $\mathrm{R}^{2}(\%)$ & Estimated Dose \\
\hline \multirow{6}{*}{ Height (cm) } & $\mathrm{N}$ & $Y^{* *}: 41.37+0.34 x-0.001 x^{2}$ & 67.1 & 170 \\
\hline & $P$ & $Y^{* *}: 38.9+0.73 x-0.004 x^{2}$ & 84.7 & 91.25 \\
\hline & K & $Y^{* *}: 37.7+0.30 x-0.0008 x^{2}$ & 91.7 & 187.5 \\
\hline & $\mathrm{Ca}$ & $Y^{*}: 36.52+46.47 x-20.42 x^{2}$ & 95.3 & 1.14 \\
\hline & $M g$ & $Y^{* *}: 36.9+109.3 x-117.5 x^{2}$ & 90.3 & 0.46 \\
\hline & $S$ & $Y^{* *}: 38.09+0.93 x-0.009 x^{2}$ & 67.2 & 51.66 \\
\hline \multirow{6}{*}{$N^{\circ}$ of leaves } & $\mathrm{N}$ & $Y^{* *}: 56.9+2.5 x-0.007 x^{2}$ & 85.6 & 178.57 \\
\hline & $P$ & $Y^{* *}: 57.1+4.35 x-0.02 x^{2}$ & 81.1 & 108.75 \\
\hline & K & $Y^{* *}: 46.39+2.08 x-0.004 x^{2}$ & 92.7 & 260 \\
\hline & $\mathrm{Ca}$ & $Y^{* *}: 59.61+336.99 x-138.05 x^{2}$ & 78.6 & 1.22 \\
\hline & $M g$ & $Y^{* *}: 49.75+896.15 x-891.07 x^{2}$ & 92.2 & 0.5 \\
\hline & $S$ & $Y^{* *}: 49.28+8.02 x-0.07 x^{2}$ & 87.3 & 57.28 \\
\hline \multirow{6}{*}{ MSF (g) } & $\mathrm{N}$ & $Y^{* *}: 1.76+0.05 x-0.0001 x^{2}$ & 66.2 & 250 \\
\hline & $\mathrm{P}$ & $Y^{* *}: 1.37+0.104 x-0.0006 x^{2}$ & 88.9 & 86.66 \\
\hline & K & $Y^{* *}: 1.35+0.004 x-0.0001 x^{2}$ & 83.7 & 20 \\
\hline & $\mathrm{Ca}$ & $Y^{* *}: 1.22+6.90 x-2.97 x^{2}$ & 94.1 & 1.16 \\
\hline & $M g$ & $Y^{* *}: 1.27+15.62 x-15.73 x^{2}$ & 89.8 & 0.5 \\
\hline & $S$ & $Y^{* *}: 1.27+0.15 x-0.001 x^{2}$ & 87.0 & 75 \\
\hline \multirow{6}{*}{$\operatorname{MSC}(g)$} & $\mathrm{N}$ & $Y^{* *}: 1.08+0.04 x-0.0001 x^{2}$ & 79.7 & 200 \\
\hline & $P$ & $Y^{* *}: 0.7+0.09 x-0.0005 x^{2}$ & 94.7 & 90 \\
\hline & K & $Y^{* *}: 0.76+0.03 x-0.00009 x^{2}$ & 78.6 & 166.67 \\
\hline & $\mathrm{Ca}$ & $Y^{* *}: 0.75+5.81 x-2.60 x^{2}$ & 83.3 & 1.12 \\
\hline & $\mathrm{Mg}$ & $Y^{* *}: 0.65+13.31 x-13.62 x^{2}$ & 82.6 & 0.49 \\
\hline & $S$ & $Y^{* *}: 0.62+0.13 x-0.001 x^{2}$ & 79.3 & 65 \\
\hline
\end{tabular}

which did not show any significant difference when submitted to increasing doses of $\mathrm{P}$ and $\mathrm{K}$.

For the results of dry mass of roots, shoot and plant, it was found that the nutrient responsible for the highest estimated average values was $\mathrm{N}$, presenting 6.22, 12.96 and $17.31 \mathrm{~g}$, respectively. It is noteworthy that this also provided similar increments for MSF and MSC (Table 4), thus characterizing it as the element of greatest influence on the yield of basil phytomass. Thus, the estimated doses for MSR were: N: 200; P: 30; K: 75 (values expressed in $\mathrm{mg} / \mathrm{dm}^{3}$ ); Ca: 1.34; $\mathrm{Mg}: 0.5$ (both in $\mathrm{cmol}_{\mathrm{c}} / \mathrm{dm}^{3}$ ) and S: $50\left(\mathrm{mg} / \mathrm{dm}^{3}\right)$. It is important to note that the values of calcium, magnesium and sulfur remained close to those tested in the reference dose. In general, it was observed that these nutrients favored significant performance in plant growth, possibly the changes in the Ca: Mg ratio positively influenced the basil plants. Work is still restricted using all macronutrients to define fertilization schemes, mainly for $\mathrm{Ca}, \mathrm{Mg}$ and $\mathrm{S}$, as they are primarily classified as secondary macronutrients, and are required in lower quantities than the others.

In the MSPA and MSP the estimated doses were: N: 225 and 175; P: 95 and 79.4; K: 17.5 and 171.87 (values expressed in $\mathrm{mg} / \mathrm{dm}^{3}$ ); Ca: 1.14 and 1.19; $\mathrm{Mg}$ : 0.49 and 0.5 (both in $\mathrm{cmol}_{\mathrm{c}} / \mathrm{dm}^{3}$ ); s: 70 and 48.75 (mg/ $\mathrm{dm}^{3}$ ), respectively. Carmo et al. (2019), studying basil growth using organic compounds inoculated with Actinobacterium, obtained similar results for shoot dry mass in the control treatment (11.5g), and significant increases in these values were highlighted with the use of inoculum.

The leaf area of basil plants was significantly influenced by all the studied nutrients, with $P$ being the one that provided the highest estimated average values $\left(384.65 \mathrm{~cm}^{2}\right)$, these results suggest that basil was demanding in terms of phosphate fertilization. The AF of a plant is directly related to photosynthesis, as it is related to the capture of light and production of carbohydrates, lipids and proteins. However, it is necessary to emphasize the source/drain ratio of these plants, where high values of AF do not always guarantee higher photosynthetic rates, due to the self-shading that contributes to reduction of the useful AF of the plant. Thus, the estimated dose for each nutrient was N: 168.9; P: 88.81; K: 186.4 (values expressed in $\mathrm{mg} / \mathrm{dm}^{3}$ ); Ca: 1.15; Mg: 0.48 (both in $\mathrm{cmol}_{c} /$ $\left.\mathrm{dm}^{3}\right)$ and $\mathrm{S}: 51.5\left(\mathrm{mg} / \mathrm{dm}^{3}\right)$.

\section{Conclusions}

Based on the dry mass data of leaves, this being the most commercially requested feature, the recommended doses for the phytomass yield of basil plants are: $250 \mathrm{mg} / \mathrm{dm}^{3}$ of $\mathrm{N}, 86.66 \mathrm{mg} / \mathrm{dm}^{3}$ of $\mathrm{P}, 20 \mathrm{mg} /$ 
Table 5. Estimates generated due to the application of increasing doses of $\mathrm{N}, \mathrm{P}, \mathrm{K}$ and $\mathrm{S}$ in $\mathrm{mg} / \mathrm{dm}^{3}$ and $\mathrm{Ca}$ and $\mathrm{Mg}$ in $\mathrm{cmol}_{\mathrm{c}} / \mathrm{dm}^{3}$, of the following variables: root dry mass (MSR), shoot dry mass (MSPA), plant dry mass (MSP) and leaf area (AF), in plants of O. basilicum, Cruz das Almas-Ba, 2018.

\begin{tabular}{|c|c|c|c|c|}
\hline Variables & Nutrients & Equation & $\mathrm{R}^{2}(\%)$ & Estimated Dose \\
\hline \multirow{6}{*}{$\operatorname{MSR}(g)$} & $\mathrm{N}$ & $Y^{*}: 2.22+0.04 X-0.0001 X^{2}$ & 53.1 & 200 \\
\hline & $P$ & $Y: 3.17+0.01 x$ & & 30 \\
\hline & K & $Y: 2.20+0.06 x$ & & 75 \\
\hline & $\mathrm{Ca}$ & $Y^{*}: 1.64+4.69 x-1.75 x^{2}$ & 75.9 & 1.34 \\
\hline & $\mathrm{Mg}$ & $Y^{* *}: 1.55+10.82 x-9.94 x^{2}$ & 74.7 & 0.5 \\
\hline & $S$ & $Y^{*}: 1.54+0.10 x-0.001 x^{2}$ & 55.0 & 50 \\
\hline \multirow{6}{*}{ MSPA (g) } & $\mathrm{N}$ & $Y^{* *}: 2.84+0.09 x-0.0002 x^{2}$ & 72.7 & 225 \\
\hline & $P$ & $Y^{* *}: 2.08+0.19 x-0.001 x^{2}$ & 93.1 & 95 \\
\hline & K & $Y^{* *}: 2.11+0.007 x-0.0002 x^{2}$ & 82.7 & 17.5 \\
\hline & $\mathrm{Ca}$ & $Y^{* *}: 1.97+12.71 X-5.56 x^{2}$ & 91.1 & 1.14 \\
\hline & $\mathrm{Mg}$ & $Y^{* *}: 1.92+28.93 x-29.36 x^{2}$ & 88.7 & 0.49 \\
\hline & $S$ & $Y^{* *}: 1.90+0.28 x-0.002 x^{2}$ & 85.4 & 70 \\
\hline \multirow{6}{*}{ MSP (g) } & $\mathrm{N}$ & $Y^{* *}: 5.06+0.14 x-0.0004 x^{2}$ & 65.3 & 175 \\
\hline & $P$ & $Y^{* *}: 4.28+0.27 x-0.001 x^{2}$ & 77.1 & 79.4 \\
\hline & K & $Y^{* *}: 3.13+0.11 x-0.00032 x^{2}$ & 93.0 & 171.8 \\
\hline & $\mathrm{Ca}$ & $Y^{* *}: 3.61+17.41 x-7.32 x^{2}$ & 86.7 & 1.19 \\
\hline & $\mathrm{Mg}$ & $Y^{* *}: 3.48+39.75 x-39.31 x^{2}$ & 84.7 & 0.5 \\
\hline & $S$ & $Y^{* *}: 3.45+0.39 X-0.004 x^{2}$ & 77.1 & 48.75 \\
\hline \multirow{6}{*}{$\mathrm{AF}\left(\mathrm{cm}^{2}\right)$} & $\mathrm{N}$ & $Y^{* *}: 118.9+3.04 x-0.009 x^{2}$ & 68.1 & 168.9 \\
\hline & $P$ & $Y^{* *}: 84.9+6.75 X-0.038 X^{2}$ & 97.0 & 88.81 \\
\hline & K & $Y^{* *}: 87.8+2.61 x-0.007 x^{2}$ & 89.3 & 186.4 \\
\hline & $\mathrm{Ca}$ & $Y^{* *}: 93.0+406.06 x-177.03 x^{2}$ & 85.3 & 1.15 \\
\hline & $\mathrm{Mg}$ & $Y^{* *}: 94.7+1042.8 x-1089.5 x^{2}$ & 88.0 & 0.48 \\
\hline & $S$ & $Y^{* *}: 93.71+9.28 x-0.09 x^{2}$ & 81.6 & 51.5 \\
\hline
\end{tabular}

$\mathrm{dm}^{3}$ of $\mathrm{K}, 1.16 \mathrm{cmolc} / \mathrm{dm}^{3}$ of $\mathrm{Ca}, 0.5 \mathrm{cmolc}^{\mathrm{d}} \mathrm{dm}^{3}$ of $\mathrm{Mg}$ and $75 \mathrm{mg} / \mathrm{dm}^{3}$ of $\mathrm{S}$, using dystrophic Argissol as substrate.

Basil plants are very demanding in $\mathrm{N}$, this being the most requested element and with the most variations in the estimated doses.

\section{Acknowledgements}

The authors thank Capes for funding the scholarship and the Federal University of Recôncavo da Bahia for their willingness to conduct this work.

\section{References}

Abreu, C.B., Santos, A.S., Souza, G.S., Oliveira, U.C., Silva, J.S. 2013. Qualidade de luz no crescimento inicial de plantas de manjericão (Ocimum Basilicum L.) em ambiente controlado. Enciclopédia Biosfera 9: 1855-1862.

Bione, M.A.A., Paz, V.P.S., Silva, F., Ribas, R.F., Soares, T.M. 2014. Crescimento e produção de manjericão em sistema hidropônico NFT sob salinidade. Revista Brasileira de Engenharia Agrícola e Ambiental 18: 1228-1234.

Blank, A.F., Rosa, Y.R.S., Carvalho Filho, J.S., Santos, C.A. Arrigoni-Blank, M.F., Niculau, E.S., Alves, P.B. 2012. A diallel study of yield components and essential oil constituents in basil. Industrial Crops and Products 38: 93-98.

Blank, A.F., Carvalho Filho, J.S., Santos Neto, A.L., Alves, P.B., Arrigoni-Blank, M.F., Silva-Mann, R., Mendonça, M.C. 2004. Caracterização morfológica e agronômica de acessos de manjericão e alfavaca. Horticultura Brasileira 22: $113-116$
BRASIL. 2012. Práticas integrativas e complementares: plantas medicinais e fitoterapia na Atenção Básica. Ministério da Saúde, Brasília, Brazil. 156 p.

Calixto, J.B. 2000. Efficacy, safety, quality control, market and regulatory guidelines for herbal medicines (phytotherapeutic agents). Brazilian Journal of Medical and Biological Research 33: 179-189.

Carmo, C.O., Silva, F., Silva, R.M., Soares, A.C.F. 2019. Utilização de compostos orgânicos inoculados com Actinobacteria na adubação do manjericão (Ocimum basilicum L.). Magistra 30: 18-27.

EMBRAPA. 2011. Manual de métodos de análise de solos. Embrapa Solos, Rio de Janeiro, Brazil. 230 p.

Hanif, M.A., Al-Maskari, M.Y., Al-Maskari, A., Al-Shukaili, A., Al-Maskari, A.Y., Al-Sabahi, J.N. 2011. Essential oil composition, antimicrobial and antioxidant activities of unexplored Omani basil. Journal of Medicinal Plants Research 5: 751-757.

Ferreira, D.F. 2011 . Sisvar: a computer statistical analysis system. Ciência e Agrotecnologia 35: 1039-1042.

Ferreira, S.D., Bulegon, L.G., Yassue, R.M., Echer, M.M. 2016. Efeito da adubação nitrogenada e da sazonalidade na produtividade de Ocimum basilicum L. Revista Brasileira de Plantas Medicinais 18: 67-73.

Furlan, M.C. 2000. Efeito da adubação com N, $\mathrm{P}_{2} \mathrm{O}_{5}$ $\mathrm{K}_{2} \mathrm{O}$ sobre a biomassa, o rendimento e composição do óleo essencial de Ocimum basilicum L. cv. genovese. 172p. (Tese de Doutorado) - São Paulo State University, 
Botucatu, Brazil.

Gonçalves, J.L.M., Santarelli, E.G., Moraes Netto, S.P., Manara, M.P., Stap, J.L. 2000. Produção de mudas de espécies nativas: substrato, nutrição, sombreamento e fertilização. Nutrição e Fertilização Florestal 1: 309-350.

Lima, J.C., Oliveira, U.C., Silva, J.S., Souza, G.S. 2013. Adubação fosfatada e qualidade de luz na produção de biomassa do capim-limão. Enciclopédia Biosfera 9: 45-55.

Oliveira, R.A., Moreira, I.S., Oliveira, F.F. 2013. Linalool and methyl chavicol present basil (Ocimum sp.) cultivated in Brazil. Revista Brasileira de Plantas Medicinais 15: 309-311.

Malavolta, E. 1980. Elementos de nutrição mineral de plantas. Agronômica Ceres, São Paulo, Brazil. 251 p.

Marques, P.A.A., José, J.V., Rocha, H.S., Fraga Júnior, E.F., Soares, D.A., Duarte, S.N. 2015. Consumo hídrico do manjericão por meio de lisímetro de drenagem. Irriga 20: 745-761.

Matos, L.S., Souza, D.S., Santos, N.S., Anjos, G.L., Santos, A.R. 2016. Crescimento inicial e índices de clorofila de manjericão cv. Maria bonita cultivado sob diferentes condições de luminosidade e concentrações de potássio. Enciclopédia Biosfera 13: 388-397.

Meira, M.R., Martins, E.R., Manganoti, S.A. 2012. Crescimento e produção de fitomassa e teor de óleo essencial de melissa (Melissa officinalis L.) sob diferentes níveis de sombreamento. Revista Brasileira de Plantas Medicinais 14: 352-357.

Peixoto, C.P., Cruz, T.V., Peixoto, M.F.S. 2011. Análise quantitativa do crescimento de plantas: Conceitos e Prática. Enciclopédia Biosfera 7: 51-76.

Pereira, R.J., Cardoso, M.G. 2012. Metabólitos secundários vegetais e benefícios antioxidantes. Journal of Biotechnology and Biodiversity 3: 146-152.

Silva, R.A.L., Soares, J.D.R., Dias, G.D.M.G., Pasqual, M. Chagas, E.A., Gavilanes, M.L. 2015. Cultivo de tamarindo sob malhas coloridas: plasticidade anatômica foliar. Ciência Rural 45: 238-244.

Souza, A.G., Amarante, C.V.T., Deschamps, F.C., Ernani, P.R. 2006. Calagem e adubação fosfatada promovem crescimento inicial e produção de hipericina em ervade-São-João. Horticultura Brasileira 24: 421-425.

Taiz, L., Zeiger, E., Moller, I.M., Murphy, A. 2017. Fisiologia e Desenvolvimento Vegetal. 6.ed. Artmed, Porto Alegre, Brazil. 858 p.

Turrent, F.A. 1979. Uso de una matriz mixta para la optimización de cinco a ocho factores controlables de la producción. Colégio de Postgraduados, Chapingo, Mexico. $65 \mathrm{p}$.
Conflict of Interest Statement: The authors declare that the research was conducted in the absence of any commercial or financial relationships that could be construed as a potential conflict of interest.

All the contents of this journal, except where otherwise noted, is licensed under a Creative Commons Attribution License attribuition-type BY. 